\title{
Comentario
}

\section{La reflexión epistemológica en Bibliotecología: necesidad, modas y arquetipos en el imaginario colectivo}

$\mathrm{C}_{\text {dios epistemológicos en Bín }}^{\text {l bemo liotecología antancia de los estu- }}$ discuten. Prueba de ello son las diferentes publicaciones, seminarios, coloquios, investigaciones que se han venido realizando en los últimos años. Por sólo mencionar algunos podemos citar la publicación de un número especial en 2005 en el Journal of Documentation en su volumen 61, Número 3, sobre Library and Information Science and the philosophy of Science dirigido por Birger Hjørland; el Seminario Pesquisa em Ciência da Informação: Epistemologia, Metodologia e Práticas, organizado por el Instituto Brasileiro de Informação em Ciência e Tecnologia (IBICT) en 2007; y el encuentro Thinking Critically: Alternative Perspectives and Methods in Information Studies, organizado por el Center for Information Policy Research, School of Information Studies of University of Wisconsin-Milwaukee, en mayo de 2008.

El interés y la necesidad de estos estudios tienen su origen en el desarrollo e introducción de diversas tecnologías en los procesos de producción, conservación, tratamiento, transmisión y uso de la información, lo que ha generado cambios en el ámbito informativo-documental de las últimas décadas; y por cuestiones económicas que convierten la información en una mercancía y al profesional de la información en un productor de plusvalía lo suficientemente hábil dentro de la sociedad actual, capitalista, desarrollada, neoliberal, denominada "sociedad de la información" como eufemismo para disfrazar esa formación económico-política.

Los beneficios que la reflexión epistemológica en Bibliotecología ofrece son, entre otros, la fundamentación de la disciplina 
que estudia el fenómeno informativo-documental, su objeto de estudio, sus límites e identidad. Así como la posibilidad de comprender el porqué de la existencia de diferentes enfoques y nombres como Biblioteconomía, Bibliotecología, Bibliotecología y Estudios de la Información, Ciencia de la Información, Ciencias de la Información, Ciencias de la Información Documental, Informática (en el sentido de Mijáilov), Documentación, Ciencias de la Documentación, etcétera. De igual modo, una vez que se han comprendido los significados de los términos anteriores es posible valorarlos, compararlos y adherirse a uno de ellos de manera congruente y fundamentada. Simultáneamente los estudios epistemológicos otorgan la oportunidad de construir y fundamentar el cuerpo teórico de la disciplina, esto es, sus conceptos y teorías, de manera sólida, clara, precisa, sin ambigüedades y sin dejarse atrapar o seducir por "modas" cambiantes en terminología. Finalmente este tipo de investigaciones contribuyen a comprender el fenómeno de la inter, multi y transdisciplina, ya que al encontrar una identidad de la disciplina, es posible entrar en interrelación con otras disciplinas sin diluirse o confundirse con ellas.

Así pues, la necesidad e importancia de los estudios epistemológicos en Bibliotecología son obvios, sin embargo existe el peligro al tratar esta temática de seguir modas o enmarcarse en ideas preconcebidas que han pasado a formar parte del imaginario colectivo. Esto acontece por ejemplo cuando se habla de "paradigma científico", o cuando se concibe la ciencia bajo el modelo positivista como un conocimiento totalmente objetivo, obtenido por un método empírico-matemático que descubre leyes naturales universales.

Es común escuchar en reuniones académicas la noción "cambio de paradigma" cuando se constatan las transformaciones en el mundo informativo-documental y su manera de estudiarlo: aparición del "objeto de información" en contraposición con el "documento"; de la "biblioteca virtual”, "electrónica”, "digital”, en lugar de la "biblioteca tradicional”, etcétera. El problema de este tipo de abordaje es que se pasa por alto, en primer lugar, la indefinición y ambigüedad de lo que es paradigma, cuestión que el mismo Kuhn reconoció. Ya en 1965, Margaret Masterman señaló que el término paradigma era utilizado en la obra de Kuhn con veintiún significados distintos. Y en 
segundo lugar, también se olvida el concepto kuhniano de inconmensurabilidad entre paradigmas, esto es, la idea de una total ruptura entre paradigmas y su imposibilidad de compararlos, por lo que hablar de "cambios de paradigmas" implica una ruptura con la historia pasada, con el capital de conocimientos acumulados para empezar una nueva historia que nada tiene que ver con la Biblioteca de Alejandría, con los sabios bibliófilos y bibliógrafos, o con los conocimientos aportados por bibliotecólogos reconocidos. Hecho que no acontece, en sentido estricto, porque parcialmente prevalece una tradición científica heredada del pasado y una conciencia de ser parte de esa historia.

Otra idea sobre lo que es la ciencia, enclavada firmemente en el imaginario colectivo de algunos miembros de la comunidad epistémica bibliotecológica, es la afirmación positivista de que ésta es un conocimiento obtenido por un método único que comprueba, mide y verifica. Además de ser un conocimiento de leyes generales y totalmente objetivo. Así pues, si no se utiliza un método científico empírico-matemático, si no se descubren leyes y si no hay una objetividad absoluta, de acuerdo con esa idea, no hay ciencia. Por lo que se busca, a toda costa, obtener datos empíricos con la aplicación de encuestas, cuestionarios, entrevistas, para después dibujar gráficas de diferentes formas y colores y verificar hipótesis; se investigan afanosamente leyes dentro del campo bibliotecológico; y por último se busca la objetividad total. Si no se llega a realizar lo anterior, se concluye que la Bibliotecología no tiene el grado de cientificidad.

Sin embargo esas ideas no son del todo ciertas, es un hecho que no todas las ciencias usan el método empírico de comprobación de hechos - existen otros métodos científicos como el hermenéutico, el fenomenológico, el histórico, entre otros-; ni descubren leyes generales - en ocasiones el conocimiento sirve para comprender, y no por eso pierde su estatus científico. Las ciencias sociales y humanas son un ejemplo de ello. Por su parte la objetividad de la ciencia ha sido criticada por la sociología del conocimiento de Karl Mannheim, Norbert Elias, Robert Merton y el mismo Thomas Kuhn. Los científicos no son ángeles que estén interesados sólo en la búsqueda y descubrimiento de la verdad, sino seres humanos con sus defectos y virtudes. En las comunidades científicas existen luchas de poder, intereses creados, grupos, pasiones, amistades y enemistades, etcétera. 
La entrega del Premio Nobel de Medicina 2008 nos hizo recordar un ejemplo de esta lucha de intereses. Como es sabido el premio se otorgó a los franceses Luc Montagnier y Françoise Barré-Sinoussi como descubridores del virus del sida y se olvidó al norteamericano Robert Gallo. Durante mucho tiempo se mantuvo una disputa sobre la paternidad del descubrimiento. Hubo acusaciones de robo, de plagio y de mentiras. Para resolver la discusión, en 1987, intervinieron actores para nada científicos, sino políticos: el entonces presidente de Estados Unidos, Ronald Reagan, y el Primer Ministro francés, Jacques Chirac, quienes firmaron el acuerdo de presentar a Montagnier y Gallo como codescubridores del VIH y de paso repartirse ambos gobiernos al $50 \%$ el dinero ingresado por los test creados para detectar el virus en la sangre. No sólo la fama, sino también el dinero jugaban un papel importante en esta disputa, lo que muestra que no únicamente el amor a la verdad, el deseo de conocer es lo que mueve a los científicos. ${ }^{1}$ Una tarea olvidada y que queda por realizar en Bibliotecología son esos estudios epistemológicos que tomen en cuenta el factor humano para comprender el desarrollo y el estado actual de la teoría bibliotecológica. Se ha creído que los únicos elementos integrantes del "paradigma científico" son conceptos, ideas, teorías; sin embargo también existen elementos extrarracionales.

Así pues, a modo de conclusión, podemos afirmar que durante la reflexión epistemológica se deben eliminar las ideas preconcebidas, abrir la visión a otras formas de hacer ciencia, no sólo la positivista, y a reconocer la influencia del factor humano en la actividad científica. Esa apertura puede dar cabida a diferentes enfoques y acercamientos epistemológicos, desde el ya mencionado positivista, hasta otros muy distintos como el pragmatista, el hermenéutico, el materialista dialéctico, el constructivista, el estructuralista, el crítico, el sociológico, en fin, cualquier planteamiento que ayude a fundamentar el cuerpo teórico de la Bibliotecología. Lo importante, a nuestro juicio, es que sea un conocimiento que resuelva cuestionamientos, se encuentre debidamente fundamentado, no cierre el horizonte interpretativo y

1 En 1991 Gallo reconoció que 'su virus' procedía de una muestra recibida del Instituto Pasteur, donde trabajaba Montagnier y habría tenido lugar una contaminación accidental de sus muestras con las francesas, por lo que no 
promueva el diálogo, la crítica y la reflexión. Esto último es lo que permitirá el ulterior desarrollo de la disciplina en los nuevos contextos que presenta este siglo XXI.

Miguel Ángel Rendón Rojas 